\title{
The karyotype of the critically endangered Lear's macaw, Anodorhynchus leari Bonaparte 1856 (Aves, Psittaciformes)
}

\author{
Denise Monnerat Nogueira ${ }^{1}$, Lucia Moreno de Souza ${ }^{1}$, Beatriz Goldschmidt ${ }^{2}$, Christiano Pinheiro da Silva ${ }^{1}$ \\ and Denise Wilches Monsores ${ }^{3}$ \\ ${ }^{1}$ Laboratório de Citogenética Animal, Faculdade de Veterinária, Universidade Federal Fluminense, \\ Niterói, RJ, Brazil. \\ ${ }^{2}$ FIOCRUZ, Rio de Janeiro, RJ, Brazil. \\ ${ }^{3}$ Fundação RIOZOO, Rio de Janeiro, RJ, Brazil.
}

\begin{abstract}
We used conventional chromosomal staining to describe the karyotype of the critically endangered Lear's macaw, Anodorhynchus leari Bonaparte 1856. A diploid number of $2 n=70$ and a karyotype similar to that of its congener Anodorhynchus hyacinthinus suggests that chromosomal rearrangements were not the main evolutionary mechanism in the genus.
\end{abstract}

Key words: birds, karyotype, chromosomes, Psittaciformes, endangered species.

Received: May 31, 2005; Accepted: May 4, 2006.

The Lear's macaw (Anodorhynchus leari Bonaparte $1856)$ is endemic to Brazil and is one of the most endangered bird species in the world as cited in Appendix I of the Convention for the International Trade of Endangered Species (CITES). According to the 2004 census carried out by the Brazilian Institute of the Environment and Renewed Natural Resources (Instituto Brasileiro do Meio Ambiente e dos Recursos Naturais Renováveis - IBAMA) there are 500 free Lear's macaw living in a restricted area in the Northeastern Brazilian state of Bahia.

Lear's macaw is one of the three species of the genus Anodorhynchus, the other two being the Glaucous macaw (Anodorhynchus glaucus Vieillot 1816), which is considered extinct (Sick, 1997), and the Hyacinth macaw (Anodorhynchus hyacinthinus Latham 1790), which although comprising nearly 5000 specimens (Collar and Juniper, 1992) is also included in Appendix I of CITES. The greatest threats to the survival of the Lear's macaw are illegal trapping and habitat destruction.

The home range of Lear's macaw was unknown for over a century but some live bird collections assigned its origin to Brazil. Finally at the end of 1978 the home of the Lear's macaw was found to be the Raso da Catarina area in

Send correspondence to Denise Monnerat Nogueira. Laboratório de Citogenética Animal, Faculdade de Veterinária, Universidade Federal Fluminense, Rua Vital Brazil Filho 64, 24230-340 Niterói, RJ, Brazil. E-mail: denisemn@ hotmail.com.
Northeastern Bahia. Most of the area is covered by deep loose sand and dense 'caatinga', a low, frequently thorny vegetation, adapted to the extremely dry climate (Sick et al., 1979).

Continued research into the general biology of this critically endangered species is clearly of enormous importance for the valid management of Lear's macaw but although studies on its breeding behavior as well as nest monitoring, habitat management and censuses have been undertaken (Yamashita, 1987; Brandt \& Machado, 1990) there was till now no information on its chromosome constitution.

In this paper we describe for the first time the karyotype of Lear's macaw and compare this karyotype with that recently published for $A$. hyacinthinus (Lunardi et al., 2003).

Two female and two male $A$. leari maintained by RIOZOO Foundation were analyzed using mitotic chromosomes obtained by the direct culture of young feather pulp (Sandness, 1954), with modifications. The chromosomes were stained with 3\% Giemsa in phosphate buffer, $\mathrm{pH} 6.8$ and examined at a 100x magnification. The description of chromosome morphology was based on Levan et al. (1964).

The diploid chromosome number for A. leari was $2 \mathrm{n}=70$, comprising 22 macrochromosomes and 48 microchromosomes. Chromosome pairs 1, 7 and 10 were meta- 
centric, pairs 2, 3, 4, 5, 6 and 9 were subtelocentric and pair 8 was submetacentric. The $\mathrm{Z}$ chromosome was a metacentric comparable in size with the fifth chromosome pair. The W chromosome was submetacentric and about the same size as chromosome 9 (Figure 1).

The karyotype of $A$. leari was similar to that of $A$. hyacinthinus described by Lunardi et al. (2003), divergence being related to chromosome pairs 5, 6 and 9 which were classified as submetacentric in A. hyacinthinus by Lunardi et al. (2003) while in A. leari they are classified as subtelocentric. These divergencies are probably related to the methodology used to classify the chromosomes, because, visually, they have the same morphology on both species.

The karyotypes of these two Anodorhynchus species are similar to those described for members of the genera Cyanopsitta, Propyrrhura, Aratinga, Pionites, Pionopsitta, Nandayus and Guaruba, distinguished by a conserved metacentric pair 1, pairs 2, 3, 4, 5, 6 varying from submetacentric to subtelocentric, pairs 7 and 8 varying from metacentric to submetacentric, and pairs 9, 10 and 11 varying from metacentric to telocentric (De Lucca, 1984; Van Dongen and De Boer, 1984; De Lucca et al., 1991; Duarte and Giannoni, 1990; Goldschmidt et al., 1997; Francisco et al., 2001; Francisco and Galetti Jr., 2001; Lunardi et al., 2003). The maintenance of the diploid number among these genera and the occurrence of variation of the centromeric position of the macrochromosomes suggests that in this group the main evolutionary mechanisms for karyotypic differentiation were inversions and/or translocations (De Lucca et al., 1991).

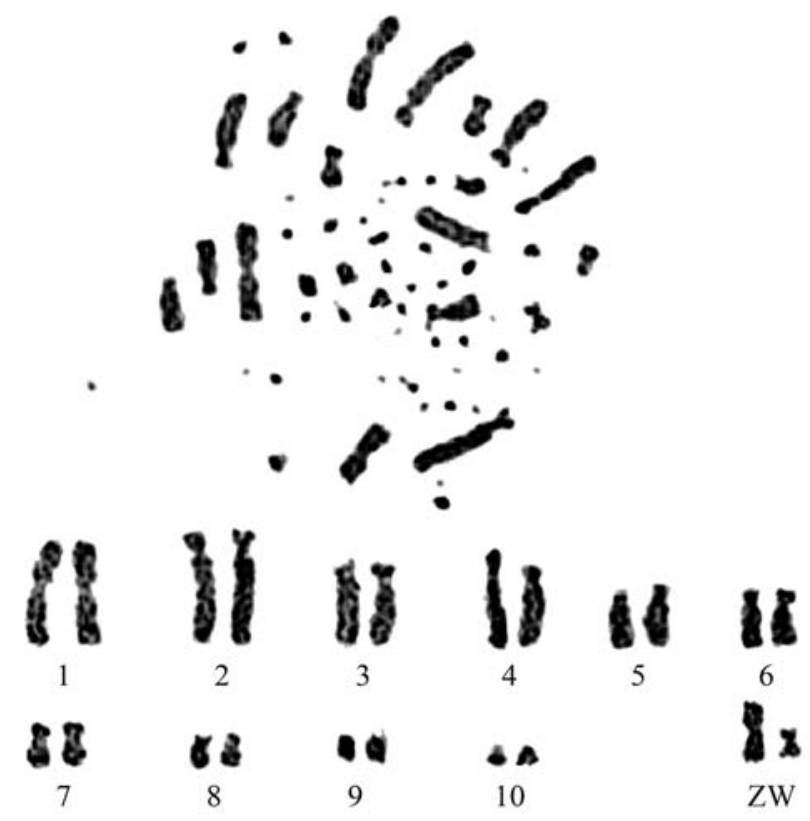

Figure 1 - Metaphase and karyotype of a female Anodorhynchus leari.

\section{Acknowledgments}

The authors thanks the Committee for the Conservation of Lear's macaw, Brazilian Institute of the Environment and Renewable Natural Resources (Instituto Brasileiro do Meio Ambiente e dos Recursos Naturais Renováveis - IBAMA) and the curators of RIOZOO Foundation for allowing access to the birds. We also thank the Brazilian National Council for the Scientific and Technological Development (Conselho Nacional de Desenvolvimento Científico e Tecnológico-CNPq) and the Research Foundation of the State of Rio de Janeiro (Fundação de Amparo à Pesquisa do Estado do Rio de Janeiro - FAPERJ) for financial support.

\section{References}

Brandt A and Machado RB (1990) Feeding area and behaviour of the Anodorhynchus leari. Ararajuba 1:57-63.

Collar NJ and Juniper AT (1992) Dimensions and causes of parrot conservation crisis. In: Beissinger SR and Snyder NFR (eds) New World Parrots in Crisis. Smithsonian Inst. Press, Washington, pp 1-23.

Convention for the International Trade of Endangered Species CITES - Appendix I. http://www.cites.org/eng/app/index. shtml.

De Lucca EJ (1974) Cariótipos de 14 espécies de aves das ordens Cuculiformes, Galliformes, Passeriformes e Tinamiformes. Rev Bras de Pesquisas Méd e Biol 7:253-263.

De Lucca EJ (1984) A comparative study of the chromosomes in 5 species of birds from the genus Aratinga. Cytologia 49:537-545

De Lucca EJ, Shirley LR and Lanier C (1991) Karyotype studies in twenty two species of parrots (Psittaciformes, Aves). Braz J Genet 14:73-98.

Duarte JMB and Giannoni ML (1990) Karyotype of the little blue macaw Cyanopsitta spixii. Braz J Genet 13:137-140.

Francisco MR, Lunardi VO and Galetti Jr. PM (2001) Chromosomal evidence of adaptive convergence in tail morphology of Neotropical psittacidae (Aves, Psittaciformes). Cytologia 66:329-332.

Francisco MR and Galetti Jr PM (2001) Cytotaxonomic considerations on Neotropical Psittacidae birds and description of three new karyotypes. Hereditas 134:225-228.

Giannoni ML, Giannoni MA and Ferrari I (1986) Citogenética Aplicada às Aves: Técnicas. Fundação de Estudos Agrários Luiz de Queiróz, Piracicaba, 121 pp.

Goldschmidt B, Nogueira DM and Monsores DW (1996) O cariótipo de Anodorhynchus hyacinthinus (Arara-azul-grande). Anais do XV Congresso Panamericano de Ciências Veterinárias (suppl):81, Campo Grande, MT.

Goldschmidt B, Nogueira DM, Monsores DW and Souza LM (1997) Chromosome study in two Aratinga species (Aratinga guarouba and Aratinga acuticaudata) (Psittaciformes). Braz J Genet 20:659-662.

Instituto Brasileiro do Meio Ambiente e dos Recursos Naturais Renováveis - IBAMA (2004) Projeto Arara-Azul-de-Lear / Relatório de Atividades. http://www.ibama.gov.br/cemave/. 
Levan A, Fredga K and Sandberg A (1964) Nomenclature for centromeric position on chromosomes. Hereditas 52:201220 .

Lunardi VO, Francisco MR, Rocha GT, Goldschmidt B and Galetti Jr PM (2003) Karyotype description of two Neotropical psittacidae species: the endangered Hyacinth Macaw, Anodorhynchus hyacinthinus, and the Hawk-headed parrot, Deroptyus accipitrinus (Psittaciformes, Aves), and its significance for conservation plans. Genetics and Molecular Biology 26:283-287.

Sandness GC (1954) A new technique for the study of avian chromosomes. Science 119:508-509.
Sick H (1997) Ornitologia Brasileira, Uma Introdução. 3rd edition. Editora Nova Fronteira, Rio de Janeiro, 862 pp.

Sick H, Teixeira DM and Gonzaga LP (1979) Our discovery of the land of the Lear's Macaw (Anodorhynchus leari). Anais da Acad Bras Ciênc 51:575-576.

Van Dongen MWM and De Boer LEM (1984) Chromosomes study of 8 species of the Cacatuidae and Psittacidae families (Aves, Psittaciformes). Genetica 65:109-117.

Yamashita C (1987) Field observations on the Indigo macaw (Anodorhynchus leari), a highly endangered species from Northeastern Brazil. Wilson Bulletin 99:280-282.

Associate Editor: Yatiyo Yonenaga-Yassuda 